\title{
ANALISIS POTENSI FINANCIAL DISTRESS DENGAN METODE SPRINGATE PADA BANK UMUM SYARIAH DI INDONESIA
}

\author{
Desi Marlinda ${ }^{1}$, Aida Yulia ${ }^{* 2}$ \\ ${ }^{1,2}$ Program Studi Akuntansi Fakultas Ekonomi dan Bisnis Universitas Syiah Kuala \\ e-mail: desiirmaya27@gmail.com ${ }^{1}$, aidayulia@unsyiah.ac.id ${ }^{2}$
}

\section{* Corresponding Author}

\begin{abstract}
Abstrak
This research aims to know the potential financial distress with Springate method at sharia banks in Indonesia. Financial ratios used is the ratio of working capital to total assets, the ratio of earnings before interest and taxes to total assets (EBIT/Total assets), the ratio of earnings before taxes to total current liabilities (EBT/current liability), and the ratio of sales to total assets. The method used in this research is quantitative research with descriptive study purposes. Data used is secondary data, in the form of an annual financial statement data sharia banks 2014-2018 period. The data analysis is done by using the method of calculation of financial ratios Springate, data is processed using a computer device tools Microsoft Excel. The results of this study indicate that all Islamic banks in the span of the last five years the average is in the category are not experiencing finan cial distress. In the calculation method Springate, 11 Islamic Banks (BUS) in Indonesia during the period 2014 to 2018 shows that only three Islamic banks that are in the unhealthy category predictions that the Bank BRI Syariah, Bank Syariah Muamalat and Bank Syariah Bukopin.
\end{abstract}

Keywords: Working Capital, Total Assets, EBIT, EBT, Current Liabilities, and Sales

\section{Pendahuluan}

Saat ini pertumbuhan dan perkembangan perekonomian di Indonesia berjalan dengan cepat. Hal ini tidak terlepas dari berbagai kegiatan usaha serta adanya peran lembaga keuangan didalamnya. Lembaga keuangan merupakan suatu badan usaha atau institusi yang bergerak di bidang jasa keuangan yang menghimpun aset dalam bentuk dana dari masyarakat lalu dana tersebut disalurkan untuk pendanaan kegiatan ekonomi dan proyek pembangunan dengan mendapatkan keuntungan dalam bentuk bunga dari dana yang disalurkan tersebut. Lembaga keuangan terbagi menjadi dua, yaitu lembaga keuangan bank dan lembaga keuangan bukan bank. Menurut UU No. 10 Tahun 1998 Pasal 1 ayat (2) sebagai hasil amandemen UU No. 7 Tahun 1992 tentang perbankan, dijelaskan bahwa bank merupakan suatu badan usaha yang bergerak dibidang penghimpun dana dari masyarakat dan menyalurkannya kembali ke masyarakat sebagai bentuk simpan pinjam atau bentuk-bentuk lainnya yang bersifat dapat meningkatkan taraf hidup masyarakat.
Di Indonesia bank dapat dibedakan menjadi dua jenis bank, yaitu bank konvensional dan bank syariah. Ketatnya persaingan antar bank syariah dengan bank konvensional mengakibatkan kedua industry tersebut bersaing memberikan dan menawarkan produk-produk terbaiknya agar bisa menarik kepercayaan masyarakat guna mempertahankan keberlangsungan usahanya dengan berbagai strategi yang telah dirancang agar dapat menghadapi berbagai risiko yang akan mengancam eksistensinya di dunia perbankan.

Berdasarkan data statistik perbankan syariah yang dikeluarkan oleh Bank Indonesia (BI) tercatat bahwa industri perbankan syariah di Indonesia mengalami perkembangan terutama Bank Umum Syariah (BUS). Data statistik Otoritas Jasa Keuangan (OJK) hingga tahun 2018 menunjukkan jumlah Bank Umum Syariah (BUS) yang ada di Indonesia telah mencapai 14 unit. Selain itu terdapat 20 Unit Usaha Syariah (UUS) dan 167 unit Bank Pembiayaan Rakyat Syariah (BPRS). Berikut disajikan tabel perkembangan bank syariah di Indonesia pada tahun 2014-2018 berdasarkan jumlah bank dan total aset 
perusahaan.

\section{Tabel 1.1}

Jaringan Kantor Perbankan Syariah dan Total Aset Gabungan BUS dan UUS

\begin{tabular}{|l|c|c|c|c|c|}
\hline \multicolumn{1}{|c|}{ Keterangan } & $\mathbf{2 0 1 4}$ & $\mathbf{2 0 1 5}$ & $\mathbf{2 0 1 6}$ & $\mathbf{2 0 1 7}$ & $\mathbf{2 0 1 8}$ \\
\hline Bank Umum Syariah (BUS) & 12 & 12 & 13 & 13 & 14 \\
\hline Unit Usaha Syariah (UUS) & 22 & 21 & 21 & 21 & 20 \\
\hline $\begin{array}{l}\text { Total Aset (Dalam jutaan } \\
\text { rupiah) }\end{array}$ & 272.343 & 296.262 & 356.504 & 424.181 & 477.327 \\
\hline
\end{tabular}

Sumber: Otoritas Jasa Keuangan, 2018.

Berdasarkan tabel tersebut, terlihat bahwa bank umum syariah terus mengalami peningkatan. Sedangkan, unit usaha syariah mengalami penurunan, hal ini dikarenakan ada beberapa unit usaha syariah yang telah berubah menjadi bank umum syariah. Dapat dilihat pada Desember 2014 di Indonesia terdapat 12 bank umum syariah dan 22 unit usaha syariah dengan total aset perbankan syariah di Indonesia lebih dari Rp 272 triliun. Sedangkan pada Desember 2018 di Indonesia tercatat 14 bank umum syariah dan 20 unit usaha syariah dengan total aset lebih dari Rp 477 triliun.

Menurut catatan Biro Riset Infobank (birl) pada tahun 2017, langkah bisnis industri keuangan syariah, khususnya perbankan syariah yang terdiri atas Unit Usaha Syariah (UUS), Bank Umum Syariah (BUS), dan Bank Pembiayaan Rakyat Syariah (BPRS), mulai bermasalah pada tahun 2013 yang disebabkan oleh permasalahan ekonomi nasional. Sehingga, banyak bank syariah yang kesulitan untuk bersaing lantaran modalnya terbatas. Misalnya, masih ada empat bank umum syariah yang modalnya dibawah $\mathrm{Rp} 1$ triliun atau tergabung dalam kelompok BUKU 1, seperti Bank Syariah Bukopin, Bank Victoria Syariah, Bank BJB Syariah, dan Bank Maybank Syariah Indonesia (www.infobanknews.com).

Penurunan kinerja keuangan yang diketahui lebih awal sangat memungkinkan bagi perusahaan, investor, dan para kreditur serta pemerintah untuk melakukan langkah- langkah antisipasi dalam mencegah agar krisis keuangan yang terjadi segera teratasi dengan baik. Menurut Platt dan Platt (2002:186) menjelaskan bahwa financial distress merupakan tahap penurunan kinerja keuangan yang terjadi sebelum terjadinya kebangkrutan ataupun likuidasi. Menurut Hofer (1980:19) financial distress merupakan kondisi dimana perusahaan mengalami laba bersih negatif selama beberapa tahun. Whitaker (1999:127) mengungkapkan bahwa financial distress adalah kondisi dimana perusahaan mengalami laba bersih negatif selama beberapa tahun dan selama lebih dari satu tahun tidak melakukan pembayaran dividen, pemberhentian tenaga kerja, atau menghilangkan pembayaran dividen. Beberapa faktor yang dapat mempengaruhi terjadinya financial distress yaitu adanya permasalahan modal atau ketidakcukupan modal, besarnya beban hutang dan bunga, serta menderita kerugian pendapatan yang dialami oleh perusahaan.

Beberapa penelitian keuangan mengenai prediksi kinerja keuangan yang menggunakan model analisis diskriminan telah banyak dilakukan, namun yang menggunakan metode Springate masih sedikit. Seperti penelitian yang dilakukan oleh Laila \& Widihadnanto (2017) terhadap kinerja bank syariah dan bank konvensional dengan menggunakan metode Bankometer sebagai unit analisis, serta penelitian Ihsan dan Kartika (2015) yang juga meneliti tentang potensi kebangkrutan pada sektor perbankan syariah untuk menghadapi perubahan lingkungan bisnis di Indonesia dengan menggunakan metode RGEC (Risk Profile, Good Corporate Governance, Earning and Capital) dan model Altman Z-Score. Penelitian ini tidak untuk menguji keakuratan metode Springate, melainkan untuk mengetahui besaran nilai prediksi kinerja keuangan atau financial distress pada bank umum syariah di Indonesia dengan menggunakan rasio-rasio keuangan yang ada dalam metode Springate.

Penelitian yang dilakukan oleh Springate (1978) mengenai pemanfaatan analisis rasio keuangan sebagai alat untuk memprediksi kebangkrutan perusahaan menyimpulkan bahwa analisis keuangan bisa digunakan untuk memprediksi kebangkrutan perusahaan. Springate akhirnya menemukan 4 rasio yang dapat digunakan dalam memprediksi adanya potensi (indikasi) kebangkrutan perusahaan yang menurut Ghodrati memiliki tingkat keakuratan hingga 92,5\%. Keempat rasio tersebut adalah rasio modal kerja terhadap total aset, rasio laba sebelum bunga dan pajak terhadap total aset, rasio laba sebelum pajak terhadap total liabilitas lancar, dan rasio total penjualan terhadap total aset. Keempat rasio tersebut 
dikombinasikan dalam suatu formula yang dirumuskan Gordon L.V. Springate yang selanjutnya terkenal dengan istilah Metode Springate (S-Score).

\section{Kajian Pustaka}

\section{Bank Syariah}

Berdasarkan UU No. 21 Tahun 2008 tentang Pebankan Syariah Pasal 1 ayat 8 menyatakan bahwa, Bank Umum Syariah (BUS) merupakan bank yang kegiatan operasionalnya memberikan jasa dalam lalu lintas pembayaran, serta dilakukan berdasarkan prinsip syariah.

\section{Laporan Keuangan}

Menurut Peraturan Standar Akuntansi Keuangan (2019) yang dikeluarkan oleh Ikatan Akuntansi Indonesia (IAI), menjelaskan bahwa laporan keuangan merupakan hasil pencatatan seluruh informasi keuangan suatu entitas yang disajikan dalam bentuk laporan yang meliputi neraca, laporan laba rugi, laporan perubahan posisi keuangan, laporan arus kas, dan catatan atas laporan keuangan lain serta memberi penjelasan yang merupakan bagian integral dari laporan keuangan.

\section{Financial Distress}

Banyak pakar yang telah mendefinisikan tentang financial distress beberapa diantaranya, Platt dan Platt (2002:186) menjelaskan bahwa financial distress merupakan tahap penurunan kinerja keuangan yang terjadi sebelum terjadinya kebangkrutan ataupun likuidasi. Menurut Hofer (1980:19) financial distress merupakan kondisi dimana perusahaan mengalami laba bersih negatif selama beberapa tahun. Whitaker (1999:127) mengungkapkan bahwa financial distress adalah kondisi dimana perusahaan mengalami laba bersih negatif selama beberapa tahun dan selama lebih dari satu tahun tidak melakukan pembayaran dividen, pemberhentian tenaga kerja, atau menghilangkan pembayaran dividen. Sementara itu Luciana (2004) mendefinisikan kondisi financial distress sebagai suatu kondisi dari perusahaan yang terdaftar di bursa saham, mengalami laba bersih dan nilai buku ekuitas negatif berturut-turut serta perusahaan tersebut telah di merger.

\section{Metode Springate}

Metode Springate ditemukan oleh Gordon L.V Springate pada tahun 1978 dengan menggunakan 40 perusahaan di Kanada sebagai sampelnya. Springate menemukan bahwa dari 19 rasio keuangan yang digunakan, hanya 4 (empat) rasio yang paling berkontribusi terhadap prediksi kebangkrtutan perusahaan. Keempat rasio keuangan tersebut dikombinasikan dalam suatu formula yang bernama model Springate.

Adapun keempat rasio keuangan tersebut yaitu antara lain sebagai berikut:

\section{Rasio Modal Kerja Terhadap Total Aset (Working Capital to Total Assets)/X1}

Modal kerja yang dimaksud adalah selisih antara aset lancar dengan utang lancar. Rasio ini adalah salah satu bentuk rasio likuiditas yang mengukur kemampuan perusahaan dalam memenuhi kewajiban jangka pendek (Kasmir, 2014). Hasil rasio tersebut dapat negatif bila aset lancar lebih kecil dari utang lancar. Meskipun penelitian ini menggunakan objek penelitiannya bank syariah, namun akun modal kerja dan total aset dalam laporan keuangan bank syariah maupun bank konvensional pengakuannya masih tetap sama, (Kartika:2015).

$$
\mathrm{X} 1=\frac{\text { Modal Kerja }}{\text { Total Aset }}
$$

\section{Rasio Laba Sebelum Bunga dan Pajak Terhadap Total Aset (Earnings Before Interest and Taxes (EBIT) to Total Assets)/X2}

Rasio ini adalah perbandingan antara laba sebelum biaya bunga dan pajak dengan total aset yang dimiliki perusahaan. Variabel ini digunakan untuk mengukur kemampuan modal yang diinvestasikan dalam keseluruhan aset untuk menghasilkan keuntungan bagi semua investor termasuk pemegang obligasi dan saham (Kasmir, 2014). Namun dalam penelitian ini, hal yang menjadi objek penelitian adalah bank umum syariah, sehingga tidak ada akun yang bernama EBIT (Earnings Before Interest and Taxes) ini dalam laporan keuangannya. Karena dalam bank syariah tidak dikenal dengan sistem bunga. Oleh karena itu, akun ini dalam laporan keuangan bank umum syariah dikenal dengan nama laba operasional/laba usaha, 
(Kartika:2015).

$$
\mathrm{X} 2=\frac{\mathrm{EBIT}}{\text { Total Aset }}
$$

\section{Rasio Laba Sebelum Pajak Terhadap Total Liabilitas Lancar (Net Earning Before Taxes to Current Liabilities)/X3}

Rasio ini digunakan untuk mengukur kemampuan perusahaan dalam melunasi utang jangka pendek. Cara menghitungnya yaitu dengan mengukur perbandingan antara laba sebelum pajak terhadap utang lancar, (Kasmir: 2014). Namun dalam penelitian ini, hal yang menjadi objek penelitian adalah bank umum syariah, sehingga akun EBT (Earnings Before Taxes) ini dalam laporan keuangan bank umum syariah dikenal dengan nama laba sebelum pajak dan zakat, (Kartika:2015).

$$
\mathrm{X} 3=\frac{\mathrm{EBT}}{\text { Liabilitas Lancar }}
$$

\section{Rasio Penjualan Terhadap Total Aset (Sales to Total Assets)/X4}

Rasio ini merupakan rasio yang membandingkan antara penjualan bersih dengan total aset. Rasio ini menunjukkan tingkat efisiensi penggunaan keseluruhan aset perusahaan (perbankan) dalam menghasilkan volume penjualan, (Kasmir: 2014). Namun, akun ini dalam laporan keuangan bank umum syariah dikenal dengan nama pendapatan pengelolaan dana oleh bank sebagai mudharib, (Kartika:2015).

$$
\mathrm{X} 4=\frac{\text { Penjualan }}{\text { Total Aset }}
$$

Dalam pembuatannya, Springate (1978) menggunakan metode yang sama dengan Altman (1968) yaitu Multiple Discriminant Analysis (MDA). Model ini memiliki akurasi 92,5\% dalam tes yang dilakukan Springate (1978). Sehingga model yang dihasilkan Springate (1978) adalah sebagai berikut:

$$
S=1,03 X 1+3,07 X 2+0,66 X 3+0,4 X 4
$$

\section{Keterangan:}

$\mathrm{S} \quad=$ Nilai Springate $(\mathrm{S}$-score)

$\mathrm{X} 1=$ Modal Kerja Terhadap Total Aset
$\mathrm{X} 2$ = Laba Sebelum Bunga dan Pajak Terhadap Total Aset

$\mathrm{X} 3$ = Laba Sebelum Pajak Terhadap Total Liabilitas Lancar

X4 = Penjualan Terhadap Total Aset

Klasifikasi perusahaan yang sehat dan tidak sehat didasarkan pada nilai standar yang ditetapkan Springate yaitu:

a) Jika nilai $\mathrm{S}>0,862$ maka perusahaan diklasifikasikan menjadi perusahaan yang sehat.

b) Jika nilai $\mathrm{S}<0,862$ maka perusahaan diklasifikasikan menjadi perusahaan yang tidak sehat.

Sesuai dengan tujuan penelitian dan kajian pustaka yang sudah dibahas, maka untuk memberikan gambaran yang jelas dan sistematis berikut kerangka pemikiran dijelaskan pada gambar 1

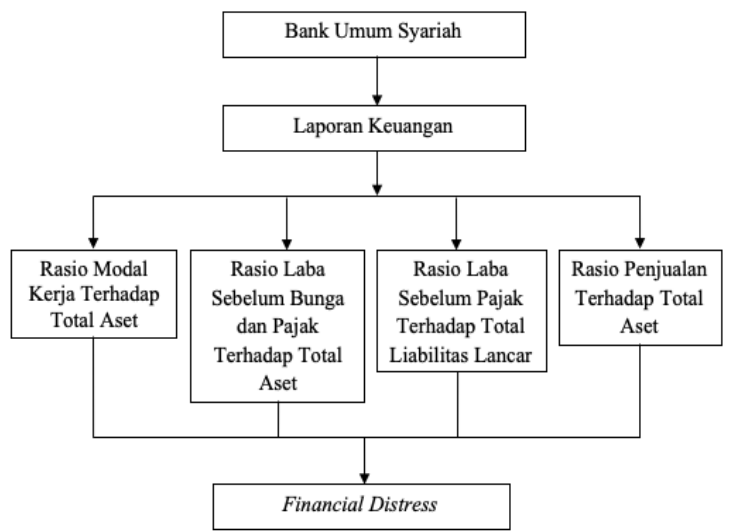

Gambar 1 Skema Kerangka Pemikiran

\section{Metode Penelitian}

\section{Sampel dan Data}

Pengambilan sampel dalam penelitian ini menggunakan purposive sampling. Penarikan purposive sampling adalah penarikan sampel dengan pertimbangan tertentu. Pertimbangan tersebut didasarkan pada kepentingan atau tujuan penelitian, sehingga sampel yang telah terpilih relevan dengan data penelitian.

Kriteria Bank Umum Syariah (BUS) yang memenuhi sebagai sampel adalah:

1) Bank syariah yang dipilih adalah bank umum syariah yang sudah berdiri lebih dari 5 tahun.

2) Bank umum syariah yang mempunyai kelengkapan data laporan keuangan yang telah diaudit dan dipublikasikan dari tahun 2014- 
2018.

Jumlah bank umum syariah di Indonesia yang menjadi kriteria sampel penelitian dapat dilihat pada Tabel 3.1.

\section{Tabel 3.1}

\section{Kriteria Sampel Penelitian}

\begin{tabular}{|c|l|c|}
\hline No. & \multicolumn{1}{|c|}{ Keterangan } & $\begin{array}{c}\text { Jumlah } \\
\text { Bank }\end{array}$ \\
\hline 1 & $\begin{array}{l}\text { Jumlah bank umum syariah di } \\
\text { Indonesia }\end{array}$ & 14 \\
\hline 2 & $\begin{array}{l}\text { Jumlah bank yang beroperasi } \\
\text { kurang dari 5 tahun }\end{array}$ & 2 \\
\hline 3 & $\begin{array}{l}\text { Jumlah bank yang beroperasi } \\
\text { lebih dari 5 tahun }\end{array}$ & 12 \\
\hline
\end{tabular}

Sumber: Otoritas Jasa Keuangan (2018), data diolah.

Berdasarkan kriteria tersebut, maka jumlah sampel yang digunakan dalam penelitian ini adalah 12 Bank Umum Syariah (BUS) di Indonesia dengan waktu pengamatan yaitu selama 5 tahun. Sehingga dari total sampel penelitian yaitu 12 bank maka akan diperoleh hasil pengamatan sebanyak 60 (5 x 12) pengamatan dari masing-masing rasio yang digunakan dalam penelitian ini. Dimana rasio yang digunakan yaitu rasio modal kerja terhadap total aset, rasio laba sebelum bunga dan pajak terhadap total aset, rasio laba sebelum bunga dan pajak terhadap total liabilitas lancar, dan rasio penjualan terhadap total aset.

Penelitian ini menggunakan sumber data sekunder berupa laporan keuangan yang telah diaudit dan dipublikasikan oleh bank umum syariah. Data diperoleh dari publikasi pemerintah yaitu Bank Indonesia dan Otoritas Jasa Keuangan dalam jangka waktu 5 tahun (2014-2018).

\section{Metode Analisis Data}

Pendekatan yang diambil dalam penelitian ini yaitu pendekatan kuantitatif menggunakan tujuan studi deskriptif. Data dalam penelitian ini diambil selama 5 tahun dari 12 bank umum syariah, kemudian di analisis per tahun kejadian. Adapun langkah- langkah yang dilakukan dalam penelitian ini yaitu sebagai berikut:

a) Pengumpulan data bank umum syariah yang terdaftar di Bank Indonesia dan Otoritas Jasa Keuangan.

b) Pengumpulan data maka diperoleh jumlah populasi dan sampel penelitian.

1) 3. Melakukan perhitungan rasio keuangan

2) pada metode Springate, dalam penelitian ini

3) penulis melakukan pengolahan perhitungan data menggunakan alat bantu perangkat komputer Microsoft Excel.

4) Melakukan analisa hasil dari nilai cut-off pada metode Springate dalam memprediksi terjadinya financial distress pada bank umum syariah.

5) Melakukan analisa nilai rata-rata (mean), maksimum dan minimum metode Springate dalam memprediksi terjadinya financial distress pada bank umum syariah.

c) Memberikan interpretasi, kesimpulan, dan saran atas hasil analisis yang dilakukan.

\section{Hasil dan Pembahasan Karakteristik Penelitian}

Penelitian ini merupakan penelitian dengan tujuan studi deskriptif. Adapun tujuan penelitian ini yaitu untuk mendeskripsikan potensi financial distress dengan metode Springate pada bank umum syariah di Indonesia.

\section{Potensi Financial Distress pada Bank Umum Syariah Periode 2014-2018 dengan Metode Springate}

Dalam metode Springate ( $S$-score) terdapat empat indikator dari rasio-rasio keuangan yang dapat dikombinasikan untuk melihat perbedaan antara perusahaan yang sehat dan tidak sehat, yaitu rasio modal kerja terhadap total aset, rasio laba sebelum bunga dan pajak terhadap total aset, rasio laba sebelum pajak terhadap total liabilitas lancar, dan rasio penjualan terhadap total aset. Sumber data yang digunakan adalah neraca dan laporan laba rugi. Berikut ini merupakan perhitungan dan analisis rasio keempat variabel Springate berdasarkan laporan keuangan yang dipublikasikan oleh bank umum syariah periode 2014-2018.

\section{Modal Kerja Terhadap Total Aset (X1)}


Tabel 4.2

Hasil Variabel X1 Bank Umum Syariah

\begin{tabular}{|c|c|c|c|c|c|c|}
\hline \multirow{2}{*}{ BUS } & \multicolumn{5}{|c|}{ Tahun } & \multirow{2}{*}{ Rerata } \\
\hline & 2014 & 2015 & 2016 & 2017 & 2018 & \\
\hline BCAS & 0,006 & 0,007 & 0,010 & 0,011 & 0,011 & 0,009 \\
\hline BNIS & 0,011 & 0,012 & 0,013 & 0,012 & 0,014 & 0,012 \\
\hline BRIS & 0,000 & 0,007 & 0,009 & 0,004 & 0,004 & 0,005 \\
\hline BMI & 0,002 & 0,003 & 0,002 & 0,001 & 0,001 & 0,002 \\
\hline BMSI & 0,031 & 0,224 & 0,107 & 0,079 & 0,133 & 0,115 \\
\hline BPDS & 0,016 & 0,011 & 0,003 & 0,111 & 0,000 & 0,028 \\
\hline BSB & 0,003 & 0,008 & 0,008 & 0,001 & 0,000 & 0,004 \\
\hline BMS & 0,001 & 0,005 & 0,006 & 0,005 & 0,009 & 0,005 \\
\hline BMIS & 0,003 & 0,001 & 0,022 & 0,013 & 0,007 & 0,009 \\
\hline BVS & 0,018 & 0,024 & 0,024 & 0,003 & 0,003 & 0,014 \\
\hline BTPNS & 0,033 & 0,048 & 0,076 & 0,099 & 0,108 & 0,073 \\
\hline
\end{tabular}

Setelah melihat tabel di atas dan kita mendapatkan hasil dari perhitungan rasio modal kerja terhadap total aset, bahwa nilai rata-rata rasio modal kerja terhadap total aset masing-masing bank syariah terlihat bahwa semua bank umum syariah tergolong sehat karena memiliki nilai rata-rata di atas nilai standar yang ditetapkan oleh Bank Indonesia yaitu 0,25 . Hasil dari data pada tabel 4.2 menunjukkan nilai rasio modal kerja terhadap total aset yang dihasilkan oleh rata-rata bank umum syariah tergolong tinggi, artinya bank umum syariah memiliki potensi yang tinggi dalam menghasilkan modal kerja bersih dari keseluruhan total aset yang dimiliki.

\section{Laba Sebelum Bunga dan Pajak Terhadap Total Aset (X2)}

\section{Tabel 4.3}

\section{Hasil Variabel X2 Bank Umum Syariah}

\begin{tabular}{|c|c|c|c|c|c|c|c|}
\hline BUS & \multicolumn{7}{|c|}{ Tahun } \\
\hline & $\mathbf{2 0 1 4}$ & $\mathbf{2 0 1 5}$ & $\mathbf{2 0 1 6}$ & $\mathbf{2 0 1 7}$ & $\mathbf{2 0 1 8}$ & Rerata \\
\hline BCAS & 0,881 & 0,893 & 0,898 & 0,858 & 0,855 & 0,877 \\
\hline BNIS & 0,829 & 0,842 & 0,820 & 0,797 & 0,752 & 0,808 \\
\hline BRIS & 0,726 & 0,737 & 0,733 & 0,751 & 0,731 & 0,736 \\
\hline BMI & 0,787 & 0,760 & 0,746 & 0,704 & 0,750 & 0,749 \\
\hline BMSI & 0,787 & 0,787 & 0,699 & 0,730 & 0,846 & 0,770 \\
\hline BPDS & 0,845 & 0,867 & 0,850 & 0,884 & 0,824 & 0,854 \\
\hline BSB & 0,800 & 0,824 & 0,777 & 0,721 & 0,698 & 0,764 \\
\hline BMS & 0,841 & 0,827 & 0,831 & 0,822 & 0,830 & 0,830 \\
\hline BMIS & 0,759 & 0,751 & 0,876 & 0,747 & 0,807 & 0,788 \\
\hline BVS & 0,429 & 0,889 & 0,823 & 0,870 & 0,802 & 0,763 \\
\hline BTPNS & 0,756 & 0,781 & 0,756 & 0,790 & 0,812 & 0,779 \\
\hline
\end{tabular}

Setelah melihat tabel di atas dan kita mendapatkan hasil dari perhitungan rasio laba sebelum bunga dan pajak terhadap total aset, bahwa nilai rata-rata rasio laba sebelum bunga dan pajak terhadap total aset masing-masing bank syariah, terlihat bahwa hanya tiga bank umum syariah yang masuk kategori sehat, yaitu Bank Maybank Syariah Indonesia, Bank Panin Dubai Syariah, dan Bank Tabungan Pensiunan Nasional Syariah karena memiliki nilai rata-rata diatas nilai standar yang ditetapkan Bank Indonesia yaitu 0,015, sedangkan delapan bank syariah lainnya masuk kategori tidak sehat karena nilai rasio laba sebelum bunga dan pajak terhadap total asetnya berada dibawah 0,015. Hasil dari data pada tabel 4.3 menunjukkan nilai rasio laba sebelum bunga dan pajak terhadap total aset yang dihasilkan oleh rata-rata bank umum syariah masih tergolong rendah, padahal semakin tinggi nilai rasio ini maka semakin besar potensi bank umum syariah dalam menghasilkan laba dari total aset perusahaan sebelum pembayaran bunga dan pajak.

\section{Laba Sebelum Pajak Terhadap Total Liabilitas Lancar (X3)}

Tabel 4.4

Hasil Variabel X3 Bank Umum Syariah

\begin{tabular}{|l|c|c|c|c|c|c|}
\hline \multirow{2}{*}{ BUS } & \multicolumn{5}{|c|}{ Tahun } & \multirow{2}{*}{ Rerata } \\
\cline { 2 - 6 } & $\mathbf{2 0 1 4}$ & $\mathbf{2 0 1 5}$ & $\mathbf{2 0 1 6}$ & $\mathbf{2 0 1 7}$ & $\mathbf{2 0 1 8}$ & \\
\hline BCAS & 0,076 & 0,038 & 0,041 & 0,080 & 0,074 & 0,062 \\
\hline BNIS & 0,104 & 0,106 & 0,099 & 0,092 & 0,088 & 0,098 \\
\hline BRIS & 0,101 & 0,100 & 0,095 & 0,089 & 0,082 & 0,093 \\
\hline BMI & 0,084 & 0,087 & 0,068 & 0,060 & 0,056 & 0,071 \\
\hline BMSI & 0,069 & 0,099 & 0,080 & 0,082 & 0,093 & 0,085 \\
\hline BPDS & 0,085 & 0,100 & 0,079 & 0,092 & 0,068 & 0,085 \\
\hline BSB & 0,051 & 0,045 & 0,035 & 0,027 & 0,027 & 0,037 \\
\hline BMS & 0,082 & 0,085 & 0,082 & 0,083 & 0,078 & 0,082 \\
\hline BMIS & 0,170 & 0,145 & 0,108 & 0,091 & 0,084 & 0,120 \\
\hline BVS & 0,104 & 0,105 & 0,075 & 0,077 & 0,080 & 0,088 \\
\hline BTPNS & 0,274 & 0,301 & 0,304 & 0,317 & 0,286 & 0,296 \\
\hline
\end{tabular}


Setelah melihat tabel di atas dan kita mendapatkan hasil dari perhitungan rasio laba sebelum pajak terhadap total liabilitas lancar, bahwa nilai rata-rata rasio laba sebelum pajak terhadap total liabilitas lancar masing-masing bank syariah, terlihat bahwa empat bank umum syariah masuk kategori tidak sehat, yaitu Bank BRI Syariah, Bank Muamalat Indonesia, Bank Syariah Bukopin, dan Bank Mandiri Syariah karena memiliki nilai ratarata dibawah nilai standar yang ditetapkan Bank Indonesia yaitu 0,05 , sedangkan tujuh bank syariah lainnya masuk kategori sehat karena nilai rasio laba sebelum pajak terhadap total liabiltas lancarnya berada diatas 0,05 . Hasil dari data pada tabel 4.4 menunjukkan nilai rasio laba sebelum pajak terhadap total liabilitas lancar yang dihasilkan oleh rata-rata bank umum syariah tergolong tinggi, artinya bank umum syariah memiliki potensi yang tinggi dalam menghasilkan laba dari total liabilitas lancar perusahaan sebelum pembayaran pajak agar mampu menutupi kewajiban lancarnya.

\section{Penjualan Terhadap Total Aset (X4)}

\section{Tabel 4.5}

\section{Hasil Variabel X4 Bank Umum Syariah}

\begin{tabular}{|c|c|c|c|c|c|c|}
\hline \multirow{2}{*}{ BUS } & \multicolumn{5}{|c|}{ Tahun } & \multirow{2}{*}{ Rerata } \\
\hline & 2014 & 2015 & 2016 & 2017 & 2018 & \\
\hline BCAS & 0,057 & 0,085 & 0,125 & 0,089 & 0,101 & 0,091 \\
\hline BNIS & 0,073 & 0,095 & 0,081 & 0,063 & 0,058 & 0,074 \\
\hline BRIS & 0,003 & 0,029 & 0,036 & 0,022 & 0,017 & 0,021 \\
\hline BMI & 0,011 & 0,013 & 0,013 & 0,006 & 0,005 & 0,010 \\
\hline BMSI & 0,154 & 1,537 & 0,475 & 0,213 & 1,015 & 0,679 \\
\hline BPDS & 0,108 & 0,090 & 0,027 & 1,565 & 0,026 & 0,363 \\
\hline BSB & 0,017 & 0,053 & 0,040 & 0,001 & 0,001 & 0,022 \\
\hline BMS & 0,003 & 0,040 & 0,040 & 0,037 & 0,058 & 0,036 \\
\hline BMIS & 0,019 & 0,019 & 0,235 & 0,076 & 0,067 & 0,083 \\
\hline BVS & 0,033 & 0,305 & 0,124 & 0,030 & 0,023 & 0,103 \\
\hline BTPNS & 0,216 & 0,291 & 0,444 & 0,582 & 0,686 & 0,444 \\
\hline
\end{tabular}

Setelah melihat tabel di atas dan kita mendapatkan hasil dari perhitungan rasio penjualan terhadap total aset, bahwa nilai rata- rata rasio penjualan terhadap total aset masing- masing bank syariah, terlihat bahwa hanya dua bank umum syariah yang masuk kategori sehat, yaitu Bank Mega Indonesia Syariah dan Bank Tabungan Pensiunan Nasional Syariah karena memiliki nilai rata-rata diatas nilai standar yang ditetapkan Bank Indonesia yaitu 0,1 , sedangkan sembilan bank syariah lainnya masuk kategori tidak sehat karena nilai rasio penjualan terhadap total asetnya berada dibawah 0,1. Hasil dari data pada tabel 4.5 menunjukkan nilai rasio penjualan terhadap total aset yang dihasilkan oleh rata-rata bank umum syariah masih tergolong rendah, padahal semakin tinggi nilai rasio ini maka semakin besar potensi bank umum syariah dalam menghasilkan volume penjualan dari total aset perusahaan yang dipergunakan secara efisien.

\section{Hasil Analisis Data Metode Springate ( $S$ - score)}

Setelah diperoleh nilai-nilai rasio keuangan masing-masing perusahaan, maka langkah penelitian selanjutnya adalah melakukan perhitungan metode Springate ( $S$ - score) dari hasil interpelasi nilai rasio tersebut. Kemudian nilai $S$-score tersebut dibandingkan dengan kriteria yang telah ditetapkan Springate agar dapat memprediksi kondisi kesehatan keuangan dari masing-masing bank umum syariah. Tabel di bawah ini merupakan hasil perhitungan Springate pada bank umum syariah di Indonesia dalam memprediksi terjadinya financial distress suatu perusahaan periode 2014-2018.

\section{Tabel 4.6}

\section{Hasil Perhitungan Metode Springate Bank} Umum Syariah Tahun 2014

\begin{tabular}{|c|c|c|c|c|c|c|}
\hline BUS & $\begin{array}{c}\mathbf{1 , 0 3} \\
(\mathbf{X 1})\end{array}$ & $\begin{array}{c}\mathbf{3 , 0 7} \\
\mathbf{( X 2 )}\end{array}$ & $\begin{array}{c}\mathbf{0 , 6 6} \\
\mathbf{( X 3 )}\end{array}$ & $\begin{array}{c}\mathbf{0 , 4} \\
\mathbf{X 4})\end{array}$ & $\begin{array}{c}\text { S- } \\
\text { score }\end{array}$ & Ket \\
\hline BCAS & 0,907 & 0,018 & 0,038 & 0,030 & 0,993 & Sehat \\
\hline BNIS & 0,854 & 0,034 & 0,048 & 0,042 & 0,978 & Sehat \\
\hline BRIS & 0,748 & 0,000 & 0,002 & 0,040 & 0,790 & $\begin{array}{l}\text { Tidak } \\
\text { Sehat }\end{array}$ \\
\hline BMI & 0,811 & 0,006 & 0,007 & 0,034 & 0,858 & $\begin{array}{l}\text { Tidak } \\
\text { Sehat }\end{array}$ \\
\hline BMSI & 0,811 & 0,095 & 0,102 & 0,028 & 1,036 & Sehat \\
\hline BPDS & 0,870 & 0,049 & 0,071 & 0,034 & 1,024 & Sehat \\
\hline BSB & 0,824 & 0,009 & 0,011 & 0,020 & 0,864 & Sehat \\
\hline BMS & 0,866 & 0,003 & 0,002 & 0,033 & 0,904 & Sehat \\
\hline BMIS & 0,782 & 0,009 & 0,013 & 0,068 & 0,872 & Sehat \\
\hline BVS & 0,442 & 0,055 & 0,022 & 0,042 & 0,561 & $\begin{array}{l}\text { Tidak } \\
\text { Sehat }\end{array}$ \\
\hline BTPNS & 0,779 & 0,101 & 0,143 & 0,110 & 1,133 & Sehat \\
\hline
\end{tabular}


Berdasarkan tabel 4.6 rumusan hasil perhitungan nilai rasio-rasio untuk mendapatkan nilai Springate ( $S$-score) pada bank umum syariah periode 2014 menunjukkan bahwa terdapat delapan bank umum syariah yang termasuk ke dalam kategori sehat, sebab nilai $S$-score yang dihasilkan lebih besar dari 0,862. Artinya delapan bank umum syariah tersebut dikategorikan dalam keadaan tidak mengalami financial distress dan tidak berisiko pada kebangkrutan. Adapun delapan bank tersebut adalah Bank BCA Syariah, Bank BNI Syariah, Bank Maybank Syariah Indonesia, Bank Panin Dubai Syariah, Bank Syariah Bukopin, Bank Mandiri Syariah, Bank Mega Indonesia Syariah, dan Bank Tabungan Pensiunan Nasional Syariah. Sedangkan tiga bank lainnya termasuk ke dalam kategori tidak sehat, sebab nilai $S$-score yang dihasilkan kurang dari 0,862. Artinya tiga bank umum syariah tersebut berpotensi mengalami financial distress dan berisiko mengalami kebangkrutan. Adapun ketiga bank tersebut meliputi Bank BRI Syariah, Bank Muamalat Indonesia dan

Bank Victoria Syariah.

Tabel 4.7

Hasil Perhitungan Metode Springate Bank Umum Syariah Tahun 2015

\begin{tabular}{|c|c|c|c|c|c|c|}
\hline BUS & $\begin{array}{c}\mathbf{1 , 0 3} \\
\mathbf{( X 1 )}\end{array}$ & $\begin{array}{c}\mathbf{3 , 0 7} \\
\mathbf{( X 2 )}\end{array}$ & $\begin{array}{c}\mathbf{0 , 6 6} \\
\mathbf{( X 3 )}\end{array}$ & $\begin{array}{c}\mathbf{0 , 4} \\
\mathbf{( X 4 )}\end{array}$ & $\begin{array}{c}\boldsymbol{S} \text { - } \\
\text { score }\end{array}$ & Ket \\
\hline BCAS & 0,920 & 0,021 & 0,056 & 0,015 & 1,012 & Sehat \\
\hline BNIS & 0,867 & 0,037 & 0,063 & 0,042 & 1,009 & Sehat \\
\hline BRIS & 0,759 & 0,021 & 0,019 & 0,040 & 0,839 & $\begin{array}{c}\text { Tidak } \\
\text { Sehat }\end{array}$ \\
\hline BMI & 0,783 & 0,009 & 0,009 & 0,035 & 0,836 & $\begin{array}{c}\text { Tidak } \\
\text { Sehat }\end{array}$ \\
\hline BMSI & 0,811 & 0,688 & 1,014 & 0,040 & 2,553 & Sehat \\
\hline BPDS & 0,893 & 0,034 & 0,059 & 0,040 & 1,026 & Sehat \\
\hline BSB & 0,849 & 0,025 & 0,035 & 0,018 & 0,927 & Sehat \\
\hline BMS & 0,852 & 0,015 & 0,026 & 0,034 & 0,927 & Sehat \\
\hline BMIS & 0,774 & 0,003 & 0,013 & 0,058 & 0,848 & $\begin{array}{l}\text { Tidak } \\
\text { Sehat }\end{array}$ \\
\hline BVS & 0,916 & 0,074 & 0,201 & 0,042 & 1,233 & Sehat \\
\hline BTPNS & 0,804 & 0,147 & 0,192 & 0,120 & 1,263 & Sehat \\
\hline
\end{tabular}

Berdasarkan tabel 4.7 rumusan hasil perhitungan nilai rasio-rasio untuk mendapatkan nilai Springate ( $S$-score) pada bank umum syariah periode 2015 menunjukkan bahwa terdapat delapan bank umum syariah yang termasuk ke dalam kategori sehat, sebab nilai $S$-score yang dihasilkan lebih besar dari 0,862. Artinya delapan bank umum syariah tersebut dikategorikan dalam keadaan tidak mengalami financial distress dan tidak berisiko pada kebangkrutan. Adapun delapan bank tersebut adalah Bank BCA Syariah, Bank BNI Syariah, Bank Maybank Syariah Indonesia, Bank Panin Dubai Syariah, Bank Syariah Bukopin, Bank Mandiri Syariah, Bank Victoria Syariah, dan Bank Tabungan Pensiunan Nasional Syariah. Sedangkan tiga bank lainnya termasuk ke dalam kategori tidak sehat, sebab nilai $S$-score yang dihasilkan kurang dari 0,862 . Artinya tiga bank umum syariah tersebut berpotensi mengalami financial distress dan berisiko mengalami kebangkrutan. Adapun ketiga bank tersebut meliputi Bank BRI Syariah, Bank Muamalat Indonesia, dan Bank Mega Indonesia Syariah.

\section{Tabel 4.8}

\section{Hasil Perhitungan Metode Springate Bank Umum Syariah Tahun 2016}

\begin{tabular}{|c|c|c|c|c|c|c|}
\hline BUS & $\begin{array}{c}\mathbf{1 , 0 3} \\
\mathbf{( X 1 )}\end{array}$ & $\begin{array}{c}\mathbf{3 , 0 7} \\
\mathbf{( X 2 )}\end{array}$ & $\begin{array}{c}\mathbf{0 , 6 6} \\
\mathbf{( X 3 )}\end{array}$ & $\begin{array}{c}\mathbf{0 , 4} \\
\mathbf{( X 4 )}\end{array}$ & $\begin{array}{c}\boldsymbol{S} \text { - } \\
\text { score }\end{array}$ & Ket \\
\hline BCAS & 0,925 & 0,031 & 0,083 & 0,016 & 1,055 & Sehat \\
\hline BNIS & 0,845 & 0,040 & 0,053 & 0,040 & 0,978 & Sehat \\
\hline BRIS & 0,755 & 0,028 & 0,024 & 0,038 & 0,845 & $\begin{array}{c}\text { Tidak } \\
\text { Sehat }\end{array}$ \\
\hline BMI & 0,768 & 0,006 & 0,009 & 0,027 & 0,810 & $\begin{array}{l}\text { Tidak } \\
\text { Sehat }\end{array}$ \\
\hline BMSI & 0,720 & 0,328 & 0,314 & 0,032 & 1,394 & Sehat \\
\hline BPDS & 0,876 & 0,009 & 0,018 & 0,032 & 0,935 & Sehat \\
\hline BSB & 0,800 & 0,025 & 0,026 & 0,014 & 0,865 & Sehat \\
\hline BMS & 0,856 & 0,018 & 0,026 & 0,033 & 0,933 & Sehat \\
\hline BMIS & 0,902 & 0,068 & 0,155 & 0,043 & 1,168 & Sehat \\
\hline BVS & 0,848 & 0,074 & 0,082 & 0,030 & 1,034 & Sehat \\
\hline BTPNS & 0,779 & 0,233 & 0,293 & 0,122 & 1,427 & Sehat \\
\hline
\end{tabular}

Berdasarkan tabel 4.8 rumusan hasil perhitungan nilai rasio-rasio untuk mendapatkan nilai Springate ( $S$-score) pada bank umum syariah periode 2016 menunjukkan bahwa terdapat sembilan bank umum syariah yang termasuk ke dalam kategori sehat, sebab nilai $S$-score yang dihasilkan lebih besar dari 0,862. Artinya delapan bank umum syariah tersebut dikategorikan dalam keadaan tidak mengalami financial distress dan tidak berisiko pada 
kebangkrutan. Adapun delapan bank tersebut adalah Bank BCA Syariah, Bank BNI Syariah, Bank Maybank Syariah Indonesia, Bank Panin Dubai Syariah, Bank Syariah Bukopin, Bank Mandiri Syariah, Bank Mega Indonesia Syariah, Bank Victoria Syariah, dan Bank Tabungan Pensiunan Nasional Syariah. Sedangkan dua bank lainnya termasuk ke dalam kategori tidak sehat, sebab nilai $S$-score yang dihasilkan kurang dari 0,862 . Artinya tiga bank umum syariah tersebut berpotensi mengalami financial distress dan berisiko mengalami kebangkrutan. Adapun ketiga bank tersebut meliputi Bank BRI Syariah dan Bank Muamalat Indonesia.

\section{Tabel 4.9}

\section{Hasil Perhitungan Metode Springate Bank} Umum Syariah Tahun 2017

\begin{tabular}{|c|c|c|c|c|c|c|}
\hline BUS & $\begin{array}{c}\mathbf{1 , 0 3} \\
\mathbf{( X 1})\end{array}$ & $\begin{array}{c}\mathbf{3 , 0 7} \\
\mathbf{( X 2})\end{array}$ & $\begin{array}{c}\mathbf{0 , 6 6} \\
\mathbf{( X 3})\end{array}$ & $\begin{array}{c}\mathbf{0 , 4} \\
\mathbf{( X 4 )}\end{array}$ & $\begin{array}{c}\text { S- } \\
\text { score }\end{array}$ & Ket \\
\hline BCAS & 0,884 & 0,034 & 0,059 & 0,032 & 1,009 & Sehat \\
\hline BNIS & 0,821 & 0,037 & 0,042 & 0,037 & 0,937 & Sehat \\
\hline BRIS & 0,774 & 0,012 & 0,015 & 0,036 & 0,837 & $\begin{array}{c}\text { Tidak } \\
\text { Sehat }\end{array}$ \\
\hline BMI & 0,725 & 0,003 & 0,004 & 0,024 & 0,756 & $\begin{array}{l}\text { Tidak } \\
\text { Sehat }\end{array}$ \\
\hline BMSI & 0,752 & 0,003 & 0,141 & 0,033 & 0,929 & Sehat \\
\hline BPDS & 0,911 & 0,341 & 1,033 & 0,037 & 2,322 & Sehat \\
\hline BSB & 0,743 & 0,003 & 0,001 & 0,011 & 0,758 & $\begin{array}{l}\text { Tidak } \\
\text { Sehat }\end{array}$ \\
\hline BMS & 0,847 & 0,015 & 0,024 & 0,033 & 0,919 & Sehat \\
\hline BMIS & 0,769 & 0,040 & 0,050 & 0,036 & 0,895 & Sehat \\
\hline BVS & 0,896 & 0,009 & 0,020 & 0,031 & 0,956 & Sehat \\
\hline BTPNS & 0,814 & 0,304 & 0,384 & 0,127 & 1,629 & Sehat \\
\hline
\end{tabular}

Berdasarkan tabel 4.9 rumusan hasil perhitungan nilai rasio-rasio untuk mendapatkan nilai Springate ( $S$-score) pada bank umum syariah periode 2017 menunjukkan bahwa terdapat delapan bank umum syariah yang termasuk ke dalam kategori sehat, sebab nilai $S$-score yang dihasilkan lebih besar dari 0,862. Artinya delapan bank umum syariah tersebut dikategorikan dalam keadaan tidak mengalami financial distress dan tidak berisiko pada kebangkrutan. Adapun delapan bank tersebut adalah Bank BCA Syariah, Bank BNI Syariah, Bank Maybank Syariah Indonesia, Bank Panin Dubai Syariah, Bank Mandiri Syariah, Bank Mega Indonesia Syariah, Bank Victoria Syariah, dan Bank Tabungan Pensiunan Nasional Syariah. Sedangkan tiga bank lainnya termasuk ke dalam kategori tidak sehat, sebab nilai $S$-score yang dihasilkan kurang dari 0,862. Artinya tiga bank umum syariah tersebut berpotensi mengalami financial distress dan berisiko mengalami kebangkrutan. Adapun ketiga bank tersebut meliputi Bank BRI Syariah, Bank Muamalat Indonesia, dan Bank Syariah Bukopin.

Tabel 4.10

Hasil Perhitungan Metode Springate Bank Umum Syariah Tahun 2018

\begin{tabular}{|c|c|c|c|c|c|c|}
\hline BUS & $\begin{array}{c}\mathbf{1 , 0 3} \\
(\mathbf{X 1})\end{array}$ & $\begin{array}{c}\mathbf{3 , 0 7} \\
\mathbf{( X 2 )}\end{array}$ & $\begin{array}{c}\mathbf{0 , 6 6} \\
\mathbf{( X 3 )}\end{array}$ & $\begin{array}{c}\mathbf{0 , 4} \\
\mathbf{( X 4 )}\end{array}$ & $\begin{array}{c}\text { S- } \\
\text { score }\end{array}$ & Ket \\
\hline BCAS & 0,881 & 0,034 & 0,067 & 0,030 & 1,012 & Sehat \\
\hline BNIS & 0,775 & 0,043 & 0,038 & 0,035 & 0,891 & Sehat \\
\hline BRIS & 0,753 & 0,012 & 0,011 & 0,033 & 0,809 & $\begin{array}{l}\text { Tidak } \\
\text { Sehat }\end{array}$ \\
\hline BMI & 0,773 & 0,003 & 0,003 & 0,022 & 0,801 & $\begin{array}{l}\text { Tidak } \\
\text { Sehat }\end{array}$ \\
\hline BMSI & 0,871 & 0,408 & 0,670 & 0,037 & 1,986 & Sehat \\
\hline BPDS & 0,849 & 0,000 & 0,017 & 0,027 & 0,893 & Sehat \\
\hline BSB & 0,719 & 0,000 & 0,001 & 0,011 & 0,731 & $\begin{array}{l}\text { Tidak } \\
\text { Sehat }\end{array}$ \\
\hline BMS & 0,855 & 0,028 & 0,038 & 0,031 & 0,952 & Sehat \\
\hline BMIS & 0,831 & 0,021 & 0,044 & 0,034 & 0,930 & Sehat \\
\hline BVS & 0,826 & 0,009 & 0,015 & 0,032 & 0,882 & Sehat \\
\hline BTPNS & 0,836 & 0,332 & 0,453 & 0,114 & 1,735 & Sehat \\
\hline
\end{tabular}

Berdasarkan tabel 4.10 rumusan hasil perhitungan nilai rasio-rasio untuk mendapatkan nilai Springate ( $S$-score) pada bank umum syariah periode 2016 menunjukkan bahwa terdapat delapan bank umum syariah yang termasuk ke dalam kategori sehat, sebab nilai $S$-score yang dihasilkan lebih besar dari 0,862. Artinya delapan bank umum syariah tersebut dikategorikan dalam keadaan tidak mengalami financial distress dan tidak berisiko pada kebangkrutan. Adapun delapan bank tersebut adalah Bank BCA Syariah, Bank BNI Syariah, Bank Maybank Syariah Indonesia, Bank Panin Dubai Syariah, Bank Mandiri Syariah, Bank Mega Indonesia Syariah, Bank Victoria Syariah, dan Bank Tabungan Pensiunan Nasional Syariah. Sedangkan tiga bank lainnya termasuk ke dalam kategori tidak sehat, sebab nilai $S$-score yang dihasilkan kurang dari 0,862 . Artinya tiga bank umum syariah tersebut berpotensi mengalami financial distress dan berisiko mengalami kebangkrutan. Adapun ketiga bank tersebut meliputi Bank BRI Syariah, Bank Muamalat Indonesia, dan Bank Syariah Bukopin. 
Perkembangan Potensi Financial Distress pada Bank Umum Syariah di Indonesia Periode 20142018 dengan Metode Springate

Berdasarkan hasil dari proses perhitungan dengan menggunakan metode Springate dapat diketahui bahwa seluruh bank umum syariah dalam rentang waktu lima tahun terakhir rata-rata berada pada kategori tidak mengalami financial distress, karena dari 11 bank umum syariah yang menjadi sampel penelitian hanya 3 bank umum syariah saja yang berada pada kategori tidak sehat atau mengalami financial distress yaitu Bank BRI Syariah, Bank Muamalat Indonesia, dan Bank Syariah Bukopin. Tabel berikut menunjukkan nilai rata-rata Springate untuk 11 bank umum syariah periode 2014-2018.

\section{Tabel 4.11}

Rata-rata Nilai Variabel Springate

\begin{tabular}{|c|c|c|c|c|c|}
\hline Tahun & $\mathbf{X 1}$ & $\mathbf{X 2}$ & $\mathbf{X 3}$ & $\mathbf{X 4}$ & Scorer \\
\hline 2014 & 0,767 & 0,011 & 0,063 & 0,109 & 0,950 \\
\hline 2015 & 0,814 & 0,032 & 0,232 & 0,110 & 1,188 \\
\hline 2016 & 0,801 & 0,025 & 0,149 & 0,097 & 1,072 \\
\hline 2017 & 0,789 & 0,031 & 0,244 & 0,099 & 1,163 \\
\hline 2018 & 0,792 & 0,026 & 0,187 & 0,092 & 1,097 \\
\hline
\end{tabular}

Berdasarkan tabel 4.11, jika dilihat selama kurun waktu lima tahun nilai Springate berfluktuatif (naik-turun). Peningkatan terjadi pada tahun 2015 dikarenakan X1 (modal kerja terhadap total aset), X2 (laba sebelum bunga dan pajak terhadap total aset), X3 (laba sebelum pajak terhadap total liabilitas lancar) dan X4 (penjualan terhadap total aset) mengalami peningkatan, sedangkan penurunan terjadi pada tahun 2016 dikarenakan menurunnya nilai semua variabel Springate. Pada tahun 2017 terjadi peningkatan kembali dikarenakan variabel X2 (laba sebelum bunga dan pajak terhadap total aset), X3 (laba sebelum pajak terhadap total liabilitas lancar), dan X4 (penjualan terhadap total aset) mengalami peningkatan. Kemudian pada tahun 2018 mengalami penurunan kembali meskipun score yang dihasilkan oleh variabel X1 (modal kerja terhadap total aset) meningkat, namun hal ini tidak memengaruhi hasil score karena nilai X2 (laba sebelum bunga dan pajak terhadap total aset), X3 (laba sebelum pajak terhadap total liabilitas lancar) dan $\mathrm{X} 4$ (penjualan terhadap total aset) mengalami penurunan.

Berikut merupakan grafik yang menunjukkan nilai rata-rata Springate pada bank umum syariah periode 2014-2018.

\section{Grafik 4.1}

Rata-rata Nilai Springate 11 Bank Umum Syariah Periode 2014-2018

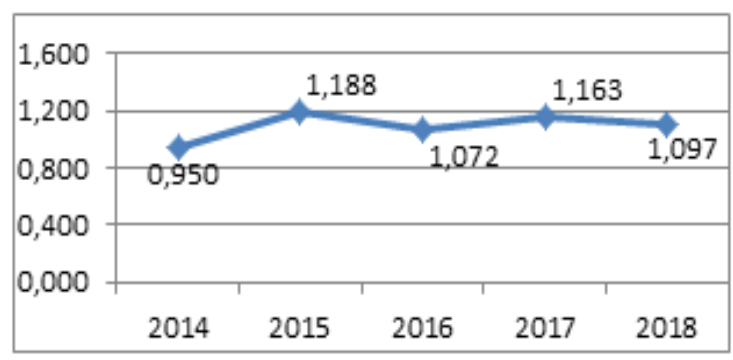

Grafik 4.1 menunjukkan bahwa tren nilai Springate bank umum syariah selama tahun 20142018 menunjukkan pergerakan fluktuatif (naik-turun). Nilai $s$-score tertinggi terjadi pada tahun 2015 dan terendah berada pada tahun 2014. Variabel yang mempunyai pengaruh lebih besar dalam menghasilkan rata-rata nilai Springate pada bank umum syariah adalah rasio X3 (laba sebelum pajak terhadap total liabilitas lancar) dibandingkan variabelvariabel lainnya.

Hal ini berarti rata-rata peningkatan utang lancar pada 11 bank umum syariah masih tinggi dibandingkan peningkatan pada laba sebelum pajak yang dihasilkannya. Semakin tinggi rasio ini menunjukkan kemampuan perusahaan dalam menutupi utang lancarnya oleh pendapatan sebelum pajak sudah sangat baik. Jadi dapat ditarik kesimpulan bahwa penurunan variabel tertinggi terjadi pada X3 (laba sebelum pajak terhadap total liabilitas lancar) sehingga menyebabkan nilai Springate berfluktuatif. Berikut ini merupakan hasil score Springate tertinggi pada 11 BUS periode 2014-2018. Hasil akan ditunjukkan pada tabel 4.12.

Tabel 4.12

Nilai Score Springate Tertinggi Periode 2014-2018

\begin{tabular}{|c|c|c|c|c|c|c|}
\hline Tahun & BUS & X1 & X2 & X3 & X4 & Score \\
\hline 2014 & BTPNS & 0,779 & 0,101 & 0,143 & 0,110 & 1,133 \\
\hline 2015 & BMBS & 0,811 & 0,688 & 1,014 & 0,040 & 2,553 \\
\hline 2016 & BTPNS & 0,779 & 0,233 & 0,293 & 0,122 & 1,427 \\
\hline 2017 & PNBS & 0,911 & 0,341 & 1,033 & 0,037 & 2,322 \\
\hline 2018 & BMBS & 0,871 & 0,408 & 0,670 & 0,037 & 1,986 \\
\hline
\end{tabular}

Berdasarkan tabel 4.12 hasil perhitungan Score Springate bank umum syariah yang memiliki nilai score tertinggi pada tiap tahunnya 
berbeda-beda. Pada tahun 2014 diraih oleh BTPN Syariah, tahun 2015 diraih oleh Bank Maybank Syariah, tahun 2016 diraih kembali oleh BTPN Syariah, tahun 2017 diraih oleh Bank Panin Dubai Syariah, dan pada tahun 2018 diraih kembali oleh Bank MaybankSyariah. Hasil perhitungan Score Springate menunjukkan bahwa, BTPN Syariah dan Bank Maybank Syariah meraih nilai tertinggi pada dua tahun berbeda. BTPN Syariah meraih nilai tertinggi pada tahun 2014 dan 2016 dengan nilai score 1,133 dan 1,427, sedangkan Bank Maybank Syariah meraih nilai tertinggi pada tahun 2015 dan 2018 dengan nilai score 2,553 dan 1,986. Kemudian pada tahun 2017 diraih oleh Bank Panin Dubai Syariah dengan nilai score 2,322. Berikut ini merupakan hasil score Springate terendah pada 11 BUS periode 2014-2018. Hasil akan ditunjukkan pada tabel 4.13 .

Tabel 4.13

Nilai Score Springate Terendah Periode 2014-2018

\begin{tabular}{|c|c|c|c|c|c|c|}
\hline Year & BUS & Xl & X2 & X3 & X4 & Score \\
\hline 2014 & BVS & 0,442 & 0,055 & 0,022 & 0,042 & 0,561 \\
\hline 2015 & BMS & 0,783 & 0,009 & 0,009 & 0,035 & 0,836 \\
\hline 2016 & BMS & 0,768 & 0,006 & 0,009 & 0,027 & 0,810 \\
\hline 2017 & BMS & 0,725 & 0,003 & 0,004 & 0,024 & 0,756 \\
\hline 2018 & BSB & 0,719 & 0,000 & 0,001 & 0,011 & 0,731 \\
\hline
\end{tabular}

Berdasarkan tabel 4.13 hasil perhitungan Score Springate bank umum syariah yang memiliki nilai score terendah pada tiap tahunnya berbeda-beda, namun umumnya diraih oleh Bank Muamalat Syariah. Pada tahun 2014 diraih oleh Bank Victoria Syariah, tahun 2015-2017 diraih oleh Bank Muamalat Syariah, dan tahun 2018 diraih oleh Bank Syariah Bukopin. Hasil perhitungan Springate menunjukkan, bahwa bank umum syariah yang memiliki nilai score terendah paling banyak selama tiga tahun berturut-turut adalah Bank Muamalat Syariah, yaitu pada tahun 2015-2017 dengan nilai score 0,$836 ; 0,810$; dan 0,756. Jika diamati bank umum syariah yang memilki nilai score terendah pada setiap tahunnya adalah bank syariah yang sedang mengalami masalah keuangan, dimana jumlah utang lancar yang dimiliki bank lebih besar dibandingkan dengan laba yang dihasilkan. Hal ini dapat dilihat dari perbandingan nilai X3 (laba sebelum pajak terhadap total liabilitas lancar) dan X2 (laba sebelum bunga dan pajak terhadap total aset) pada Bank Muamalat
Syariah. Kemudian pada tahun 2014 dan 2018 nilai terendah diraih oleh Bank Victoria Syariah dan Bank Syariah Bukopin dengan nilai score 0,561 dan 0,731.

\section{Analisis Potensi Financial Distress dengan Metode Springate pada Bank Umum Syariah di Indonesia}

Analisis potensi terjadinya financial distress pada bank umum syariah di Indonesia periode 2014 2018 dengan menggunakan metode Springate menunjukkan beberapa hasil diantaranya yaitu, dari 11 bank umum syariah, tujuh bank umum syariah yang mengalami penurunan laba bersih selama beberapa tahun atau satu tahun terakhir dan empat bank umum syariah yang mengalami peningkatan laba yakni Bank BCA Syariah, Bank BNI Syariah, Bank Mandiri Syariah dan Bank Tabungan Pensiunan Nasional Syariah. Dari empat bank yang mengalami kenaikan laba selama 5 tahun berturut-turut hanya Bank Mandiri Syariah saja yang mengalami laba negatif pada tahun 2014, namun semua bank masih dikategorikan sehat menurut perhitungan metode Springate dalam periode 2014-2018. Hal ini dikarenakan pada perhitungan metode Springate naik turunnya score lebih besar dipengaruhi oleh variabel X3 (laba sebelum pajak terhadap total liabilitas lancar). Maka dari itulah meskipun mengalami laba negatif akan tetapi kewajiban jangka pendek yang dimiliki oleh bank tersebut pun kecil. Hal inilah yang menyebabkan Bank Mandiri Syariah tetap mendapat prediksi sehat pada tahun 2014.

Sementara itu, dari tujuh bank yang mengalami penurunan laba selama beberapa tahun atau satu tahun terakhir ada 4 bank yang mendapatkan kategori sehat menurut perhitungan metode Springate dalam periode 2014-2018. Adapun ke empat bank tersebut adalah Bank Maybank Syariah, Bank Panin Dubai Syariah, Bank Mega Indonesia Syariah,

dan Bank Victoria Syariah. Meskipun Bank Mega Indonesia Syariah pada tahun 2015 dan Bank Victoria Syariah pada tahun 2014 dikategorikan tidak sehat, namun secara umum kedua bank tersebut dikategorikan sehat. Hal ini berarti semua variabel pada metode Springate memiliki nilai rasio keuangan yang baik.

Berdasarkan hasil penelitian tersebut menunjukkan bahwa, kondisi keuangan bank umum syariah menunjukkan hasil yang cenderung 
meningkat. Hasil ini di dapat karena kegiatan usaha yang dilakukan baik dalam kegiatan penghimpunan dan penyaluran dana oleh bank syariah cenderung aman. Maksud aman disini adalah bank syariah dalam melakukan transaksi berlandaskan pada aset dasar (underlying assets) untuk menghindari terjadinya transaksi "money to money" yang dapat dikategorikan sebagai riba, dan kegiatan penyaluran dana bank syariah lebih ke arah sektor riil dalam perekonomian domestik. Berbeda dengan bank konvensional yang kegiatan usahanya cenderung lebih kearah spekulatif dengan melakukan transaksitransaksi keuangan yang mempunyai risiko tinggi. Spekulatif disini maksudnya adalah dengan tergantung pada tingkat suku bunga, karena keuntungan terbesar bank konvensional didapatkan dari selisih antara besarnya bunga yang dikenakan kepada para peminjam dana dengan imbalan bunga yang diberikan kepada nasabah.

Jika diperhatikan dari 11 Bank Umum Syariah (BUS) di Indonesia rasio yang memberikan pengaruh lebih besar dalam memprediksi financial distress adalah rasio likuiditas dibandingkan dengan rasio profitabilitas, jadi ketika perusahaan mengalami penurunan laba bersih selama beberapa tahun atau satu tahun terakhir, itu tidak bisa dijadikan sebuah indikator bahwa perusahaan mengalami financial distress. Hal ini dibuktikan dalam penelitian ini pada metode Springate rasio likuiditas yang mempengaruhi besarnya score dalam memprediksi financial distress adalah rasio laba sebelum pajak terhadap total liabilitas lancar.

\section{Implikasi Kebijakan dalam Menghindari Risiko Kebangkrutan}

Hasil penelitian ini dapat menjadi bahan masukan dan acuan untuk memprediksi

kondisi bermasalah bank. Kemudian metode prediksi kondisi bermasalah bank ini dapat juga digunakan sebagai early warning system oleh pihak pengelola bank. Sehingga pengelola bank dapat segera melalukan antisipasi atau pencegahan apabila bank tersebut diprediksi bermasalah, agar bank yang bersangkutan tidak mengalami kondisi keuangan yang lebih buruk lagi yaitu kebangkrutan serta hendaknya bagi manajemen bank minimal satu tahun sekali melakukan evaluasi terhadap kinerja keuangannya.
Salah satu hal yang dapat diperhatikan oleh manajemen Bank Umum Syariah (BUS) sebagai bahan evaluasi dalam hasil penelitian ini adalah pihak bank yang mengalami kondisi bermasalah untuk memperbaiki kinerja menurut perhitungan Springate, yaitu manajemen harus meningkatkan laba sebelum pajak terhadap total liabilitas lancar dimana laba bersih sebelum pajak dan zakat yang dihasilkan oleh bank harus lebih besar dari kewajiban utang jangka pendek yang harus dibayarnya. Oleh karena itu, untuk dapat menghasilkan laba yang lebih besar bank syariah perlu melakukan efisiensi biaya.

\section{Kesimpulan dan Saran Kesimpulan}

Berdasarkan hasil penelitian dan pembahasan yang telah dijabarkan sebelumnya, maka dapat ditarik kesimpulan bahwa hasil dari proses perhitungan dengan menggunakan metode Springate dapat diketahui bahwa:

a) Seluruh bank umum syariah dalam rentang waktu lima tahun terakhir rata- rata berada pada kategori tidak mengalami financial distress.

b) Pada perhitungan metode Springate, 11 Bank Umum Syariah (BUS) di Indonesia periode 2014-2018 menunjukkan hanya 3 bank umum syariah yang berada pada prediksi kategori tidak sehat yaitu Bank BRI Syariah, Bank Muamalat Syariah, dan Bank Syariah Bukopin. Bank Syariah Bukopin pada tahun 2014 hingga 2016 masih termasuk dalam kategori sehat, namun pada tahun 2017 hingga 2018 masuk ke dalam prediksi kategori tidak sehat. Kemudian Bank BRI Syariah dan Bank Muamalat Syariah secara berturut- turut, yaitu pada tahun 2014 hingga 2018 masuk ke dalam kategori tidak sehat. Hal tersebut dikarenakan nilai yang dihasilkan kurang dari nlai cut-off yaitu 0,862 .

c) Score Springate bank umum syariah yang memiliki nilai score tertinggi pada tiap tahunnya berbeda-beda. Pada tahun 2014 diraih oleh Bank Tabungan Pensiunan Negara Syariah, tahun 2015 diraih oleh Bank Maybank Syariah, tahun 2016 diraih kembali oleh Bank Tabungan Pensiunan Nasional Syariah, tahun 2017 diraih oleh Bank Panin Dubai Syariah, dan pada tahun 2018 diraih kembali oleh Bank 
MaybankSyariah. Bank Tabungan Pensiunan Nasional Syariah meraih nilai tertinggi pada tahun 2014 dan 2016 dengan nilai score 1,133 dan 1,427, sedangkan Bank Maybank Syariah meraih nilai tertinggi pada tahun 2015 dan 2018 dengan nilai score 2,553 dan 1,986. Kemudian pada tahun 2017 diraih oleh Bank Panin Dubai Syariah dengan nilai score 2,322.

\section{Saran}

Peneliti menyadari penelitian ini masih jauh dari kesempurnaan, untuk itu berdasarkan hasil penelitian, maka penulis

memberikan saran sebagai berikut:

1) Hasil menunjukkan bahwa terdapat bank umum syariah yang mengalami kondisi financial distress pada metode Springate disebabkan karena naik turunnya rasio laba sebelum pajak terhadap total liabilitas lancar. Oleh karena itu, untuk dapat menghasilkan laba yang lebih besar selain dari meningkatkan pendapatan perusahaan, bank syariah perlu melakukan efisiensi biaya.

2) Berdasarkan hasil penelitian 11 Bank Umum Syariah (BUS) di Indonesia dikategorikan dalam keadaan yang sehat dan tidak mengalami financial distress sehingga bank syariah dapat menjalankan usahanya dengan lancar. Jadi, masyarakat juga tidak perlu ragu untuk menyimpan atau menginvestasikan dananya di bank umum syariah.

3) Bagi peneliti selanjutnya diharapkan dapat menambahkan objek dan rentang waktu penelitian, menggunakan beberapa metode pembanding lainnya seperti metode Almant Zscore, metode Grover, dan metode RGEC, serta mengolah hasil penelitian dengan uji statistik.

\section{Daftar Pustaka}

AAOIFI. 2017. Accounting and Auditing and Governance Standards for Islamic Financial Institutions. Manama, Bahrain: AAOIFI.

Almilia, Luciana Spica dan Emanuel Kristijadi. 2006. Prediksi Kondisi Financial Distress Perusahaan Go Public Dengan Menggunakan Analisis Multinomial Logit. Jurnal Ekonomi dan Bisnis. Vol. 12 No. 1. hal:. 1-2.

Amaliah, Indri. 2016. Analisis Rasio Keuangan Dengan Model Zmijewski (X-Score) Dalam Memprediksi Kebangkrutan Pada Perbankan Syariah di Indonesia Periode 2012-2015.
Skripsi S1 Ekonomi Tidak Dipublikasikan. Jakarta: Program Muamalat (Ekonomi Islam) Fakultas Syariah dan Hukum Universitas Islam Negeri Syarif Hidayatullah.

Bank Indonesia. 2018. Statistik Perbankan Syariah. Jakarta: Bank Indonesia.

Bustamam, Ridwan Ibrahim, dan Dedy Saputra. 2015. Analisis Penyajian Laporan Keuangan Syariah Pada Baitul Mal Provinsi Aceh. Jurnal Dinamika Akuntansi dan Bisnis. Vol. 2 No. 1. hal:82-91.

Bowo, Unggul Nusantoro Ari dan Sri Ayem. 2013. Analisis Perbandingan Model Altman Modifikasi dan Springate untuk Memprediksi Kebangkrutan Pada Perusahaan Perbankan yang Terdaftar di Bursa Efek Indonesia Sebelum dan Sesudah Adanya Lembaga Penjamin Simpanan. Jurnal Akuntansi. Vol. 1 No. 2. hal:11-21.

DSN MUI. 2003. Himpunan Fatwa Dewan Syariah Nasional edisi 2. DSN- MUI dan Bank Indonesia. Edi dan May Tania. 2018. Springate, Zmijewski, dan Grover dalam Memprediksi Financial Distress. Jurnal Reviwe Akuntansi dan Keuangan. Vol. 8 No. 1. hal: 79- 92.

Edward, I. Altman. 1968. Financial Ratios, Discriminant Analysis and The Prediction Of Corporate Bankcruptcy. The Journal of Finance. Vol. 23 No. 4. hal:. 594.

Endri. 2009. Prediksi Kebangkrutan Bank untuk Menghadapi dan Mengelola Perubahan Lingkungan Bisnis: Analisis Model Altman's Z- Score. Perbarnas Quarterly Review. Vol. 2 No. 1. hal: 37-42.

Halim, M. H. 2012. Analisis Laporan Keuangan. Yogyakarta: Unit Penerbit dan Percetakan Sekolah Tinggi Ilmu Manajemen YKPN.

Hassan, M. Kabir, and Mervyn K. Lewis. 2007. Handbook of Islamic Banking. Cheltenham: Edward Elgar.

Hery. 2015. Analisis Laporan Keuangan.Edisi 1. Yogyakarta: Center for Academic Publishing Services.

Hofer, C. W. 1980. Turnaround Strategies. Journal of Business Strategy. Vol. 1 No. 1. hal: 19-31.

Ihsan, Dwi Nur'aini dan Sharfina Putri Kartika. $2015 . \quad$ Potensi Kebangkurtan Pada Sektor Perbankan Syariah Untuk Menghadapi Perubahan Lingkungan Bisnis. Jurnal Etikonomi. Vol. 14 No. 2. hal: 113-146.

Ikatan Akuntan Indonesia. 2019. Pernyataan Standard Akuntansi Keuangan Penyajian Laporan Keuangan Syariah. Jakarta: Ikatan Akuntan Indonesia. 
Infobanknews. 2018. Analisis Strategi Perbankan dan Keuangan Infobank. Vol. XL. No. 479. hal: 92-93.

2019. Analisis Strategi Perbankan dan Keuangan. Infobank. Vol. XL. No. 490. hal: 66-67.

Kartika, Syarfina Putri. 2015. Potensi Kebangkrutan pada Sektor Perbankan Syariah untuk Menghadapi Perubahan Lingkungan Bisnis dengan Menggunakan Model Altman Z- score Modifikasi. Skripsi S1 Ekonomi Skripsi S1 Ekonomi Tidak Dipublikasikan. Jakarta: Program Muamalat (Ekonomi Islam) Fakultas Syariah dan Hukum Universitas Islam Negeri Syarif Hidayatullah.

Kasmir. 2014. Analisis Laporan Keuangan. Jakarta: PT Raja Grafindo Persada.

Kurniawati, Lintang dan Nur Kholis. 2014. Analisis Model Predeksi Financial Distress Pada Perusahaan Perbankan Syariah di Indonesia. Syariah Paper Accounting FEB UMS. hal: 145.

N, Laila \& Widihadnanto F. 2017. Financial Distress Prediction Using Bankometer Model on Islamic and Conventional Banks : Evidence from Indonesia. Int. Journal of Economics and Management. Vol. 11. hal: 169-18.

Nada, Shofaun. 2013. Penerapan Metode Multiple Discriminant Analysis untuk Mengukur Tingkat Kesehatan yang Mengindikasikan Gejala Financial Distress Pada Bank Umum Syariah. Jurnal Al- Iqtishad. Vol. V. No. 2. hal:119-235.

Nurasiya, Siti. 2016. Analisis Penggunaan Metode Altman Z-Score, Springate, Dan Zmijewski dalam Memprediksi Potensi Financial Ditress pada Bank Umum Syariah di Indonesia Periode 2011-2014. Skripsi S1 Ekonomi Tidak Dipublikasikan. Jakarta: Program Muamalat (Ekonomi Islam) Fakultas Syariah dan Hukum Universitas Islam Negeri Syarif Hidayatullah.

Nurcahyani. 2015. Studi Komparatif Model Z-Score Altman, Springate, dan Zmijewski Dalam Mengindikasikan Kebangkrutan Perusahaan Yang Terdaftar Di BEI. Artikel Ilmiah. Universitas Negeri Padang.

Nurhayati, Sri. Wasilah. 2015. Akuntansi Syariah Indonesia. Jakarta: Salemba Empat.

Nuzul, Hafis dan Maya Febrianty Lautania. 2015. Pengaruh Leverage, Financial Distress dan Growth Options Terhadap Aktivitas Hedging pada Perusahaan Non-Keuangan yang Terdaftar di Bursa Efek Indonesia. Jurnal Dinamika Akuntansi dan Bisnis. Vol. 2 No. 2. hal:104-113.
Platt, Harlan D dan Platt, Marjorie B. 2002. Predicting Corporate Financial Distress: Reflections on Choice-Based Sample Bias. Journal of Economics and Finance. Vol. 26 No. 2. hal: 184-199.

Rahmaniah, Melan dan Hendro Wibowo. 2015. Analisis Potensi Terjadinya Financial Distress Pada Bank Umum Syariah (Bus) Di Indonesia. Jurnal Ekonomi dan Perbankan Syariah. Vol. 3. No.1. hal: 1-20.

Setyowati, Tulis Wahyuni. 2018. Analisis Risiko Kebangkrutan Pada Bank Umum Syariah Di Indonesia Dengan Menggunakan Metode ZScore Periode 2013-2017. Artikel Skripsi Universitas Nusantara PGRI Kediri. hal: 2.

Sugiarto. 2017. Metodologi Penelitian Bisnis. Yogyakarta: Penerbit Andi.

Surat Edaran Bank Indonesia No. 9/24/DPbS/Tahun 2007 tentang Sistem Penilaian Tingkat Kesehatan Bank Umum Berdasarkan Prinsip Syariah.

Umam, Khaerul. 2013. Manajemen Perbankan Syariah. Bandung: CV. Pustaka Setia.

Undang-Undang Republik Indonesia Nomor 10 Tahun 1998 tentang Perubahan UU No. 7 Tahun 1992 tentang Perbankan.

Undang-Undang Republik Indonesia Nomor 21 Tahun 2008 tentang Perbankan Syariah.

Whitaker, R. B. 1999. The Early Stages of Financial Distress. Journal of Economics and Finance. Vol. 23 No. 2. hal: 123-132.

www.bank.century.com,. Diakses pada 17 April 2019.

www.bank.ifi.com,. Diakses pada 17 April 2019.

www.bi.go.id,. Diakses pada 4 Februari 2019

www.cnbcindonesia.com,. Diakses pada 19 April 2019.

www.finansial-bisnis.com,. Diakses pada 19 April 2019.

www.infobanknews.com,. Diakses pada 28 Maret 2019 www.ojk.go.id,. Diakses pada 23 Februari 2019 